\title{
Student Team Achievement Division (STAD):Its Effect on The Academic Performance of EFL Learners
}

\author{
Danebeth T. Glomo-Narzoles, Ph.D ${ }^{1}$ \\ Department of Languages and Literature \\ Center for General Education \\ AMA International University-Bahrain
}

\begin{abstract}
This study inquired on the effect of Student Team Achievement Division (STAD), a cooperative learning approach in enhancing the academic performance of the English as Foreign Language (EFL) learners. Fifty four students enrolled in the English Communication Skills 2 course were used as subjects of the study. STAD was used in the experimental group while the traditional teaching method was employed for the control group. This investigation utilized the Quasi-Experimental Design. The pre-test mean scores were the bases in determining the initial knowledge schema of the participants. After the conduct of the selected topics employing STAD, the students were given a post-test. Results showed the students who were exposed to STAD had enriched academic performance in the English Communication Skills 2 course. Seemingly, results on the post-test mean scores of the participants revealed that there is a significant effect on the academic performance of the experimental group in which the STAD had been introduced. As such, students exposed to STAD performed better than students who were taught in the traditional teaching method. Moreover, results exemplify that there is a significant relationship between the students' attitudes toward English and their academic performance in the course.
\end{abstract}

Keywords: STAD, academic performance, EFL

\section{INTRODUCTION}

Cooperative learning has been one of the interventions used by teachers to foster academic enhancement among students. On the other hand, some educators utilize cooperative learning in order to ensure active learning among the students who are the core of the educative process.

Hung, Tan, and Koh (2006) believes that active learning is a provision for students to be responsible for their own learning through constant idea conception and social interaction with their co-learners.

John Dewey has been one of the propagators of cooperative learning. He stressed education as a means to let people thrive cooperatively in a social milieu. Kurt Lewin, a social psychologist also emphasized the importance of group dynamics in getting to know the various behaviors of both the leaders and members in groups. ( Smith, K. and Conrad, J, 1992).

Cooperative learning is seen beneficial especially in a diverse classroom environment where students differ from religion, culture, race, etc. With this comes the need to choose teaching and learning strategies that would aid in educating a variety of students. More so that there has been a demand to integrate other skills in the academe, especially social skills so students will be able to succeed beyond the academic environment.

Iqbal (2010), Macpherson (2009), Slavin (1992, in Norman, 2005) acknowledged cooperative learning as one of the successful techniques that can be applied in the classroom. Cooperative learning has even brought positive results on the students' academic experience compared to the usual traditional teaching method. Moreover, it is believed that cooperative learning is a structured and systematic way of designing activities in a learning environment in which everybody gets to participate. In so doing, students' experiences become rich and valuable.

Among the numerous cooperative learning methods, the present investigation used Students Team Achievement Division, popularly known as STAD, as a tool for intervention that may reinforce EFL learners' achievement in the English Communication Skills 2 course. It has been observed that few delve on the value of this method in a classroom where in the students are learning English as a Foreign Language (EFL).

${ }^{1}$ Corresponding Author:dtglomo@amaiu.edu.bh 
Modern day theories of foreign or second language learning earmark the significance of student centered learning where much learning is done through student to student interaction.

Rai (2007), Norman (2005), and Slavin (1994) advanced that STAD is one cooperative learning strategy that boosts not only collaboration and but also independent learning at the same time. This strategy is very applicable and adaptable to different levels of students since classes are organized based on heterogeneous groupings. It is also ensured that students should have accelerated learning since STAD converges on the precepts that students work together to learn and the same time would be responsible for their own learning.

Slavin (1994) also added that the goal of STAD is to achieve students' learning as a team and to capitulate that a task would not be completed if not all members understand the content. As such, Slavin delineated the three STAD precepts which are responsibility, teamwork and equality among the students.

Hence, STAD is seen to foster good interaction among students, to enhance positive attitude towards the course, to boost self-confidence, to improve academic performance, and to increase interpersonal skills of AMA International University (AMAIUB) students who are EFL learners. Hence, this study.

This investigation has its underpinnings on the social constructivist theory which defines the role of the significant others in learning, specifically, in learning EFL.

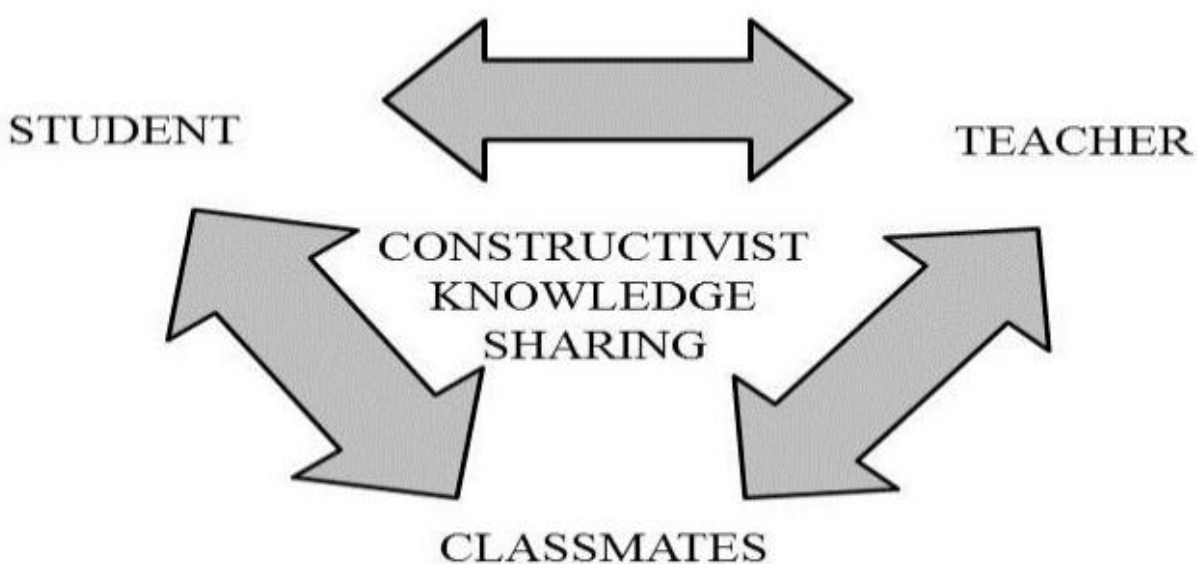

Fig1. Social Constructivism

Source:http://fultonbeth.edublogs.org/2011/01/21/social-constructivism

Figure1exemplifies an ideal constructivist classroom wherein learning is best when there is a collaborative effort of the teacher, the student, and his or her classmate. A constructivist environment is concerted and cooperative learning strategies, such as STAD, introduced by the teacher in the day-to-day classroom activities.

\subsection{Objectives of the Study}

This investigation ascertained the effect of the Student Team Achievement Division (STAD) on the academic performance of EFL learners.

Specifically, this sought answers on these questions

- What are the students' attitudes toward English?

- What are the pre-test and post-test mean scores of students exposed to STAD and traditional teaching method?

- Are there significant differences between the pre-test and post-test mean scores of students exposed to STAD and traditional teaching method?

- Is there a significant relationship between the students' attitudes towardEnglish and their academic performance in English?

Based on the aforementioned problems, the following null hypotheses were advanced

$>$ There are no significant differences between the pre-test and post-test mean scores of students exposed to STAD and traditional teaching method. 
$>$ There is no significant relationship between the students' attitudes toward English and academic performance in English.

\subsection{Research Paradigm}

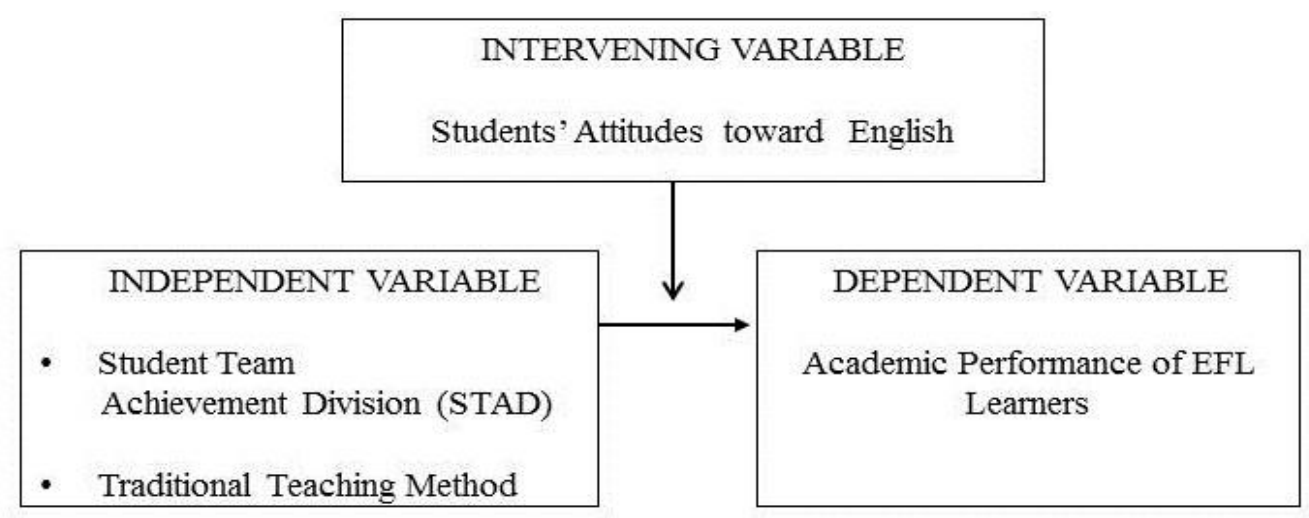

Fig2. The Research Paradigm

Figure 2 exhibits the paradigm of the study. This research work aimed to point out possible academic performance divergence between the students in the experimental group subjected to STAD and the control group subjected to Traditional Teaching method.

The EFL learners' attitude toward English isproposed to be a probable factor in the academic performance of students in the English Communication Skills 2 course.

\section{REVIEW OF RELATED LITERATURE AND STUDIES}

A number of theories and researches had been fostered to promote cooperative learning strategies in the classroom. Wyk (2010) who used STAD to determine the economic literacy levels of students; Majoka, et. al (2010) who identified an empirical evidence about the effectiveness of STAD in Mathematics classroom; Adesoji and Ibraheem (2009) who found out math ability based on the outcomes in chemistry topic using STAD; Balfakih (2003) who identified the efficacy of STAD in chemistry; and Kinney (1989) who conducted a research on students in a biology course had found out that experimental groups exposed to STAD had increased academic performance in their respective courses.

On the other hand, some researchers compared and contrasted various learning with STAD.

Tarim and Akdeniz (2008) who compared the mean scores impact of STAD and Team Individualization (TAI) on the students' math performance and attitudes toward math found out that STAD is effective than TAI.

Slavin (1980) compared nine various cooperative learning methods; Mills (2001) and Newman and Thompson (1987) asserted that STAD was the most successful cooperative learning technique for enhancing students' academic achievement in various fields of discipline.

However, several research results contradicted that STAD can boost the learners' academic performance.

Khan's research (2011) results showed no significant difference on students' achievement in Chemistry when STAD was utilized in the experimental group. These results were corroborated by Abuand Flowers (1997) who investigated on students taking up home economics, and Courtney, Courtney and Nicholson (1992) who introduced STAD in the graduate students and also found no significant differences the academic achievement of the experimental and control groups.

In the context of learning EFL, correlates that create impact in the learning process such as intelligences, attitudes, apprehensions, academic performance, capacities, behaviors, stages, motivations, among others are considered (Gardner, 1960; Shams, 2008).

Nonetheless, Fakeye (2010) recognized that the student's attitude is one of the imperative elements that influence proficiency in the language.

Moreover, EFL students' attitude to the language is a concept that elucidates their linguistic behavior which may either be positive or negative, favorable or unfavorable (Mamun, A. et.al. 2012). 


\section{MeThodology}

This research utilized the Quasi-Experimental Design or the pretest-posttest control group design. This provided framework for the effects of the independent variable to the dependent variable comprising the experimental and control groupings.

STAD was used for the experimental group while the traditional teaching method was employed for the control group. This was only limited on the selected topics in the English Communication Skills 2 course during the Prelim Period of the Second Trimester, Academic Year 2012-2013.

In the experimental group, the teacher presented the topic in the form of lecture, demonstration and discussion. After this, the students were grouped into five heterogeneous teams. The groups then intensively studied the handouts, notes, and other resource materials. After this, the teacher gave the questions, either in a form of a quiz or seatwork activities regarding the topic discussed. The students then answered individually without any help from their group mates. The mean scores of the respective teams were identified in order to get the team's score. The teacher then identified the best three teams and recognized them by giving rewards and praises. After this, the teacher gave follow-up activities to the students in the form of homework or assignment.

In the case of the traditional teaching method, the usual lecture discussion, assignment, seatwork activities and exercises were done to the control group.The wereno groupings; as such, students practiced independent learning.

This research adapted the five point Likert scale questionnaire on Students' Attitudes toward English (Glomo, 2009) in determining the perceptions of students in learning English which may either be positive or negative.

To determine the academic performance of EFL learners in the selected topics of the English CommunicationSkills 2 course, a Teacher Made Test developed by the researcher was used. The content validity of the instrument was determined through a two-way Table of Specification. Pre-test was conducted to both the experimental and control groups to identify the learners' academic performance in English.

For statistical analyses, mean, percentage, t-test, ANCOVA, and Pearson-r correlation were utilized.

\section{RESULTS AND DISCUSSION}

Table1. Students' Attitudes toward English

\begin{tabular}{|c|c|c|c|c|}
\hline \multirow[t]{2}{*}{ Statement } & \multicolumn{2}{|c|}{ Respondents } & \multirow[t]{2}{*}{ Mean } & \multirow{2}{*}{$\begin{array}{l}\text { Descriptive } \\
\text { Interpretation }\end{array}$} \\
\hline & Experimental & Control & & \\
\hline $\begin{array}{l}\text { 1.The development of our country is } \\
\text { possible mainly by educated people } \\
\text { who know English well. }\end{array}$ & 4.52 & 4.60 & 4.56 & Strongly Agree \\
\hline $\begin{array}{l}\text { 2. The use of English in government } \\
\text { and business offices helps in getting } \\
\text { things done easily. }\end{array}$ & 4.72 & 4.68 & 4.70 & Strongly Agree \\
\hline $\begin{array}{l}\text { 3. English should be a compulsory } \\
\text { subject in primary and secondary } \\
\text { schools. }\end{array}$ & 4.64 & 4.56 & 4.60 & Strongly Agree \\
\hline $\begin{array}{l}\text { 4. English should be the medium of } \\
\text { instruction in the various levels of } \\
\text { education. }\end{array}$ & 4.71 & 4.69 & 4.70 & Strongly Agree \\
\hline $\begin{array}{l}\text { 5. English films are enjoyable } \\
\text { than films in any language. }\end{array}$ & 4.55 & 4.60 & 4.58 & Strongly Agree \\
\hline $\begin{array}{l}\text { 6. English aids me understand my } \\
\text { lessons and participate in classroom } \\
\text { discussions. }\end{array}$ & 4.74 & 4.76 & 4.75 & Strongly Agree \\
\hline $\begin{array}{l}\text { 7. English proficiency will pave a way } \\
\text { for a better career, with a good job } \\
\text { and a better salary. }\end{array}$ & 4.68 & 4.65 & 4.67 & Strongly Agree \\
\hline \multirow{2}{*}{$\begin{array}{l}\text { 8. I feel that English will make me a } \\
\text { more knowledgeable person, and } \\
\text { I know that it will } \\
\text { contribute to my future } \\
\text { success. } \\
\text { Average }\end{array}$} & 4.70 & 4.74 & 4.72 & Strongly Agree \\
\hline & 4.66 & 4.66 & 4.66 & Strongly Agree \\
\hline
\end{tabular}




\section{American Research Journal of English and Literature, Volume 1, Issue 4, August 2015 ISSN 2378-9026}

Table 1 presents the students' attitudes toward English. The data show that the students strongly agree in the given statements which denote that they have a positive attitude toward English which would eventually have favorable effects in their course of learning the language.

This had been confirmed by Fakeye (2010) who recognized that the student's attitude is one of the imperative elements that influence proficiency in the language.

Table2. Test of Difference on the Pre-test and Post-test Mean Scores of the Participants

\begin{tabular}{lccccc}
\hline Participants & $\mathrm{N}$ & $\mathrm{Mean}$ & $\mathrm{t}$ & $\mathrm{df}$ & Sig. (2-tailed) \\
\hline Pre-test & & & & & \\
$\quad$ Experimental Group & 28 & 8.52 & -.402 & 46.856 & .664 \\
$\quad$ Control Group & 26 & 8.64 & & & \\
Post-test & & & & & \\
$\quad$ Experimental Group & 28 & 15.12 & .448 & 48.242 & $.000^{*}$ \\
$\quad$ Control Group & 26 & 12.60 & & & \\
\hline
\end{tabular}

Table 2 exemplifies the mean of the participants' pre-test and post-test scores on the achievement test given after the treatment period of the study. Prior to the treatment phase, it can be noted that the control group ( $\mathrm{M}=8.52)$ performed better than the experimental group $(M=8.64)$. Conversely, the experimental group $(M=15.12)$ established better achievement than the control group (12.60) as manifested by the mean scores.

Moreover, Table 2 presents the test of difference on the participants' scores during the pre-test and post-test. Results show that in the pre-test phase, no significant difference was noted on the pre-test mean scores of the participants with p-value of .685 at 0.05 significance level. As such, null hypothesis which states that there is no significant difference on the participants' prior learning in English Communication Skills 2 course is accepted.

However, the post-test mean scores revealed that there is a significance difference between the experimental and control groups' academic performance with a p-value of .000 at .05 significance level. Accordingly, the null hypothesis of no significant difference on the participants' mean scores in the post-test is rejected.

These results had been corroborated by Iqbal (2010), Macpherson (2009),Rai (2007),Norman (2005)Slavin (1992, in Norman, 2005), Slavin (1994) who acknowledged cooperative learningas one of the successful techniques that can be applied in the classroom and advanced that STAD can boostnot only collaboration and but also independent learning atthe same time.

In addition, studies of Wyk (2010),Majoka, et.al (2010), Adesoji and Ibraheem (2009), Tarim and Akdeniz (2008), Balfakih (2003), Mills (2001), and Kinney (1989), Newman and Thompson (1987), Slavin (1980) verified findings of the present investigation.

It can be established that the inclusion of STAD as one of the contemporary strategies in teaching EFL is more effective than traditional teaching.

This has been confirmed by the social constructivist theory which advances the role of the significant others in learning, definitely, in learning EFL. This is best typified by the collaborative effort of the teacher, the student, and his or her classmates.

However, research results of Khan (2011), Abu and Flowers (1997), and Courtney and Nicholson (1992) contradictedthe findings of the present investigation.

Table3. The Relationship between the Students' Attitudes toward English and their Academic Performance in English

\begin{tabular}{lcccccccccc}
\hline & \multicolumn{8}{c}{ Students' } & Attitudes toward English \\
\hline Post-test & 1 & 2 & 3 & 4 & 5 & 6 & 7 & 8 \\
Pearson Correlation & $.547^{*}$ & $.451^{*}$ & $.545^{*}$ & $.432^{*}$ & $.556^{*}$ & $.445^{*}$ & $.436^{*}$ & $.558^{*}$ \\
Sig. (2-tailed) & .000 & .001 & .000 & .002 & .001 & .000 & .003 & .000 \\
N & 54 & 54 & 54 & 54 & 54 & 54 & 54 & 54 \\
& & & & & & & & &
\end{tabular}

*Significant at 0.05 level (2-tailed) 
Legend:

1. The growth of a country relies on educated people who are proficient in English.

2. English usage in public and private offices facilitatework efficiency and effectiveness.

3. English should be anobligatorycoursein primary and secondary education.

4. English should be the language of instruction in other languages.

5. English aids me understand my lessons and to participate in classroom discussions.

6. English proficiency will pave a way for a better career, with a good job and a better salary.

7. I feel that English will make me a more knowledgeable person, and I know that it will contribute to my future success.

Table 3 reveals that there is a significant relationship between the leaners' attitudes toward English and academic performance in English. All of the statements had p-values of $<.05$ level of significance. It can be gleaned that positive attitudes in learning EFL led to their enhanced academic performance in English. Consequently, the null hypothesis of no significant relationship between the students' attitudes toward English and their academic performance in English had been rejected.

This is affirmed by Mamun, A. et.al.( 2012) who stated that EFL students' attitude to the language is a concept that elucidates their linguistic behavior which may either be positive or negative, favorable or unfavorable.

Hence, STAD is one great strategy which fostered good interaction, enhanced positive attitudes toward English, and improved the academic performance in the English Communication Skills 2 course of AMAIUB students who are EFL learners.

\section{CONCLUSIONS}

Based on the findings, the following conclusions are drawn

4.1. The AMAIUB students have positive attitudes toward English. They have recognized the integrative and instrumental benefits of English proficiency.

4.2. Students exposed to STAD have enhanced academic performance in English than students employed with the traditional teaching method. It can be recognized that STAD, one of the contemporary strategies in teaching EFL, is more effective than traditional teaching.

4.3. Positive attitudes toward English connote attainment of the course intended learning outcomes and better academic performance in English.

\section{REFERENCES}

[1] Abu, R.B., and Flowers, J. (1997). Effect of Cooperative learning Methods on Achievements, Retention and Attitude of Home Economics Students in North Carolina, Journal of Vocational and Teacher Education, 13(2). [Online] Available: http://scholar.lib.vt.edu/ejournals/JVTE/v13n2/Abu.html

[2] Adesoji, F. and Ibraheem, 1. (2009). Effects of student teams-achievement divisionsstrategy and Mathematics knowledge on learning outcomes in chemical kinetics. Available: http:/www.Sosyalarastirmalar.com/ cilt2 /sayi6pdf/ adesoji_ibraheem.pdf

[3] Balfakih, NMA. ( 2003). The effectiveness of student team achievement division (STAD) for teaching highschool chemistry in the United Arab Emirates.International Journal of Science Education, 5(5):605 - 624. http://www.informaworld.com

[4] Berry, W.( 2008).Surviving Lecture: A pedagogical alternative. College Teaching, 56(3): 149-153.

[5] Bonoparte, EPC. (1990). The effects of cooperative versus competitive classroom organization for mastery learning on the mathematical achievement and self-esteem of urban second grade pupils. Dissertation Abstracts International, 50(7): 1911

[6] Fakeye, D. (2010). Students' Personal Variables as Correlates of Academic Achievement in English as a Second Language in Nigeria.Journal of Social Sciences, 22(3), 205-211.

[7] Khan, G. (2011).Effect of Student's Team Achievement Division (STAD) on Academic Achievement of Students. Available: www.ccsenet.org/ass

[8] Majoka, M. et.al (2010). Student Team Achievement Division (STAD) as an active learning strategy: empirical evidence from mathematics classroom. Available http:// cuin561su12.wikispaces.com/file /view/ Student+ Team Achievement+ Division+(STAD) +article.pdf

[9] Mamun, A.et.al.(2012).Students' Attitudes towards English: The Case of Life Science School of Khulna University. Retrieved from http://irssh.com/yahoo_site_admin/assets/docs/20_IRSSH-264-V3N1.131231435.pdf 
American Research Journal of English and Literature, Volume 1, Issue 4, August 2015

ISSN 2378-9026

[10] Rai, N., \& Samsuddin,S. (2007). STAD Vs Traditional teaching, Redesigning Pedagogy -crpp conference 2007.[Online] Available http://conference.nie.edu.sg/2007/paper/papers/STU349.pdf

[11] Shams, M. (2008).Students' attitudes, motivation and anxiety towards English language learning. Journal of Research, 2(2), 121-144.

[12] Slavin, R.E. (1996). Research for the Future: Research on cooperative Learning and achievements: what we know, what we need to know?, Contemporary Educational Psychology, 21, 4369.http://dx.doi.org/10.1006/ceps.1996.0004

[13] Slavin, R.E. (1990). Cooperative learning: theory research and practice. Englewood

cliffs, NJ Prentice Hall.

[14] Wyk, M. (2009). Do Student Teams Achievement Divisions Enhance Economic Literacy? A Quasi-experimental Design. Available: http://www.krepublishers.com/02-Journals

[15] Tateyama-Sniezek KM 1990. Cooperative learning: Does it improve the academic achievement of students with handicaps? Exceptional Children. 56: 1-34

[16] Tarim K, Akdeniz F 2008. The effects of cooperative learning on Turkish elementary students' mathematics achievement and attitude towards mathematics using TAI and STAD methods. Educational Studies in Mathematics. 67(1): 77-91. http://www.springerlink.com/content/y52816481542x725. 